\title{
Closed Colles' Fracture
}

National Cancer Institute

\section{Source}

National Cancer Institute. Closed Colles' Fracture. NCI Thesaurus. Code C34495.

An extra-articular traumatic break in the distal radius with dorsal displacement of the distal fragment that does not involve a break in the adjacent skin. 